\title{
TALAK KARENA ISTRI TIDAK BERSEDIA BERHUBUNGAN BADAN
}

\author{
Faisol Rizal \\ Institut Agama Islam Bani Fattah Jombang, Indonesia \\ Email: mahrusabi@gmail.com \\ Sofi'ulloh \\ Institut Agama Islam Bani Fattah Jombang, Indonesia \\ Email: mahrusabi@gmail.com
}

\begin{abstract}
Abstrak
Peradilan agama merupakan salah satu pelaksana kekuasaan kehakiman bagi rakyat kecil pencari keadilan yang beragama Islam mengenai perkara perdata tertentu. Dalam kasus istri yang tidak bersedia diajak hubungan layaknya suami istri menyebabkan terjadinya perselisihan dan pertengkaran terusmenerus dan tidak ada harapan untuk bersatu, sehingga majelis hakim menjadikan alasan perceraian. Hal ini sesuai dengan UU No. 1 tahun 1972 dalam penjelasan pasal 39 ayat (2), PP. No. tahun 1975 pasal (19) huruf F dan KHI pasal 116 huruf $F$ yang berbunyi : Antara suami dan istri terusmenerus terjadinya perselisihan dan pertengkaran dan tidak ada harapan akan hidup rukun lagi dalam rumah tangga.

Dalam hal ini pengadilan juga memperhatikan keterangan -keterangan saksi yang saling berkaitan dan yang paling lemah ketika hakim tidak bisa mendamaikan kedua belah pihak karena pihak perempuan (termohon) tidak bisa datang tanpa alasan yang sah sehingga putusan diputus verstek.

Dalam memutuskan perkara majelis hakim tetap konsisten memperhatikan, mempertimbangkan, dan mendasarkan putusannya kepada peraturan yang ada pada hukum acara yang berlaku di pengadilan umum dan juga hukum khusus yang berlaku di pengadilan dalam lingkungan pengadilan
\end{abstract}


agama yang diatur dalam undang-undang, yaitu : HIR/R/Bg/BW/UU No. 2 Tahun 1986, UU No. 7 tahun 1989, tentang Peradilan Agama, UU No. 1 tahun 1974, tentang Undang-undang Perkawinan jo PP No. 9 tahun 1975, tentang Penjelasan Undang-undang Perkawinan, Undang No. 20 tahun 1947 tengang Peradilan Ulangan di Jawa dan Madura, Impres No. 1 tahun 1991 (KHI), Peraturan Mahkamah Agung, Surat Edaran Mahkah Agung, Peraturan Menteri Agama, Keputusan Menteri Agama, kitab-kitab fiqih Islam dan hukum yang tidak tertulis lainnya, dan Yurisprudensi MA.

Keyword: Talak, Istri, Berhubungan Badan 